\title{
Anti-tumor immunological response induced by cryoablation and anti- CTLA-4 antibody in an in vivo RM-1 cell prostate cancer murine model
}

\author{
F. $\mathrm{LI}^{1}$, Z. GUO ${ }^{1, *}$, H. YU ${ }^{1}$, X. ZHANG ${ }^{2}$, T. SI ${ }^{1}$, C. LIU ${ }^{1}$, X. YANG ${ }^{1}$, L. QI ${ }^{3}$
}

${ }^{1}$ Department of Interventional Treatment, Tianjin Medical University Cancer Hospital and Institution, Tianjin Key Laboratory of Cancer Prevention and Therapy, Huanhuxi Road, Hexi District, Tianjin, China 300060; ${ }^{2}$ Department of Lymphoma \& Myeloma, The University of Texas MD Anderson Cancer Center, Houston, TX, USA; ${ }^{3}$ Laboratory of Molecular Neuro-Oncology, Texas Children's Cancer Center, Houston, TX, USA.

${ }^{*}$ Correspondence: guozhivip50@126.com

Received January 26, 2014 / Accepted March 17, 2014

\begin{abstract}
Cryoablation combination therapy with blockade of the T-cell inhibitory receptor CTL-associated antigen-4 (CTLA-4) may augment the anti-tumor immune response (ATIR). It is crucial to determine the duration of ATIR after cryoablation and anti-CTLA-4 antibody therapy to determine the most appropriate treatment interval of therapy. To investigate the characteristics of ATIR induced by cryoablation and anti-CTLA-4 antibody therapy, we developed a prostate cancer model system to test the capacity of cryoablation and anti -CTLA-4 antibody to generate ATIR. Mice were randomly assigned to receive no treatment (group A), cryoablation only (group B), cryoablation plus anti-CTLA-4 antibody (group C), or anti-CTLA-4 antibody only (group D). We collected specimens on days 0, 7, 14 and 21 to study the ATIR through different techniques. Our results indicated that cryoablation induced ATIR and further enhanced this effect and reduced the number of distant metastases through combination with anti-CTLA- 4 antibody. ATIR induced by cryoablation was achieved through decreasing regulatory T cell (Treg) number. The number of Tregs induced by cryoablation was lowest on day 14 but then returned to preoperative levels on day 21, indicating that ATIR induced by cryoablation was time-dependent. However, ATIR induced by anti-CTLA-4 antibody might be mainly achieved through influencing Treg function, which was exactly not by decreasing Treg number and still maintain its ATIR effect on day 21 after therapy. In conclusion, ATIR induced by cryoablation was achieved through decreasing Treg number and is time-dependent, whereas ATIR caused by anti-CTLA-4 antibody was achieved exactly not by decreasing Treg number and not time-dependent in the first 21 days after therapy.
\end{abstract}

Key words: T cells, prostate cancer, immune response, cryoablation, anti-CTLA-4 antibody

Prostate cancer is currently one of the most common malignant cancers in adult males [1]. Prostatectomy and radiotherapy are considered to be the most effective curative therapies for early-stage prostate cancer. However, there is no curative treatment for locally advanced or metastatic prostate cancer. Cryoablation and immunotherapy have recently emerged as potential alternative therapeutic approaches [2]. Cryoablation has the advantages of being minimally invasive and being more repeatable, showing better repeatability, and providing improved immunity following treatment compared with traditional surgical approaches. Cryoablation has been used to treat many types of inoperable tumors, including prostate cancer and liver cancer [3]. As early as the 1970s, Ablin showed that freezing the prostate in patients with metastatic cancer caused regression of metastases [4]. In addition, cryoablation has been shown to induce an anti-tumor immune response (ATIR) [5].
A recent study by us found that combination therapy of cryoablation and renal embolization in patients with advanced renal cell cancer increased helper $\mathrm{T}$ cells and decreased regulatory T cells (Tregs) in peripheral blood [6]. Other evidence has indicated that cryoablation induces both a tumor-specific T-cell response in tumor-draining lymph nodes (TDLNs) and a systemic response in a mouse model of mammary adenocarcinoma $[7,8]$. In most cases, however, tumor-specific $\mathrm{T}$ cells ultimately fail to control tumor growth. These results suggest that tumor-specific $\mathrm{T}$ cells may be suppressed by Tregs in the tumor microenvironment and that the removal of Tregs may enhance the ATIR.

Tregs play an indispensable role in the immune system by suppressing effecter $\mathrm{T}$ cells and other immune cells [9]. Tregs can also dampen immune responses against various types of cancer $[10,11]$. Tregs are a $\mathrm{CD} 4^{+} \mathrm{CD} 25^{+}$population that 
expresses a high level of Foxp3 transcription factor, which is vital for the differentiation and function of Tregs [12]. Several molecular mechanisms of suppression by Tregs have been described, especially the suppression of T cells [13]. The Tcell inhibitory receptor CTL-associated antigen 4 (CTLA-4) is constitutively expressed in human and murine Tregs and is exposed on the cell surface upon activation $[14,15]$. Tregs can modulate the function of antigen-presenting cells through CTLA-4 to express immunosuppressive effects [13]. Hence, blockade of CTLA- 4 with an antibody is a strategy for eliciting ATIR. However, CTLA-4 is involved in only some aspects of suppression of Tregs. The immunosuppressive effects of Tregs could also be expressed through compensatory mechanisms involving transforming growth factor- $\beta$ (TGF- $\beta$ ) or could be activated by T-cell receptors in the presence of interleukin 2 (IL-2) $[16,17]$. Indeed, Tregs can suppress a variety of immune cells, including $B$ cells, natural killer cells, natural killer $T$ cells, CD4+ cells, CD8+ T cells, and CD4+CD25- conventional T cells.

Cryoablation is minimally invasive. After the procedure, the necrotic tumor lesion remains within the body and the dying cells may release tumor antigens that activate a tumorspecific immune response. Zhou et al. reported that in patients with hepatocellular carcinoma, the number of Tregs and the number of Foxp3+ cells infiltrating the tumors decreased significantly following cryoablation [18]. These results may correlate with the ATIR induced by cryoablation. Waitz et al. reported that the combination of cryoablation and CTLA-4 blockade augmented ATIR and the rejection of tumor metastases in their setting [19]. Thus, it may be possible to develop effective immunotherapy for prostate cancer if the number or suppressive function of Tregs can be controlled. However, so little is known about this topic that much further study is needed before this goal can be achieved.

Still less is known about the function of Tregs in prostate cancer after cryoablation. There have been very few human or mouse studies on changes in Treg levels after cryoablation in prostate cancer. In addition, we know of no study that has addressed the characteristics of the ATIR after cryoablation. Our current study was designed to investigate the characteristics of the ATIR induced by cryoablation and anti-CTLA- 4 antibody therapy in a mouse model of prostate cancer, with the ultimate goal of determining the most appropriate treatment interval for cryoablation therapy.

\section{Materials and methods}

Mice and cell lines. Six- to eight-week-old male C57BL/6 mice were purchased from the experimental animal center of Tianjin Medical University. Mice were bred, housed, and treated according to approved institutional animal protocols and were used for experiments no earlier than 5 days after their arrival. Hormone-independent RM-1 prostate cancer cells were purchased from the Cell Bank of the Shanghai Institutes for Biological Sciences. These cells were cultured in RPMI
1640 (SH30809.01B; HyClone) with 10\% fetal bovine serum (SH30084.03; HyClone), maintained in an incubator at $37^{\circ} \mathrm{C}$ in a $5 \% \mathrm{CO}_{2}$ atmosphere, grown to about $90 \%$ confluency in $25-\mathrm{cm}^{2}$ culture bottles, and harvested with trypsin. After being washed three times with phosphate-buffered saline (PBS), cells in suspension were counted and then resuspended at $1 \times 10^{7} / \mathrm{ml}$ in PBS. RM- 1 cells $\left(1 \times 10^{7}\right)$ were intradermally injected into the left flank of each mouse. For the tumor challenge, mice (25 per group) were randomly assigned to receive no treatment (group A), cryoablation only (group B), cryoablation plus antiCTLA-4 antibody (group C), or anti-CTLA-4 antibody only (group D). In total, about 370 mice were used in this study including two times repeating experiment.

Cryoablation and CTLA-4 antibody injection. Cryoablation and CTLA- 4 antibody injection were both administered on day 1 , when the primary tumors reached about $8-10 \mathrm{~mm}$ in the longest diameter, about 21 days after tumor inoculation. The mice were anesthetized by an intraperitoneal injection of a ketamine/xylazine mixture $(23.75 \mathrm{mg} / \mathrm{ml}$ ketamine +1.25 $\mathrm{mg} / \mathrm{ml}$ xylazine; $100 \mu \mathrm{l} / 25 \mathrm{~g}$ ). Mice from groups $B$ and $C$ were prepped by shaving the targeted area and cleansing it with alternating $70 \%$ alcohol rinse and povidone-iodine scrub before surgery. A $1.7-\mathrm{mm}$ cryoablation probe (Endocare Per Cryo) was inserted into the tumor, and freezing was administered for 60-90 seconds under a working pressure of $17,225 \mathrm{kPa}$ (2500 psi) and a temperature of $-110^{\circ} \mathrm{C} \sim-125^{\circ} \mathrm{C}$ at the needle hub. After the ablation, the site was monitored for bleeding and other postprocedural complications. Standard recovery procedures were implemented. Mice in groups $\mathrm{C}$ and $\mathrm{D}$ were intraperitoneally injected with $100 \mu \mathrm{g}$ of anti-CTLA- 4 antibody (UC10-4B9; BioLegend) in $0.2 \mathrm{ml}$ of PBS on the same day. Two mice from group B and four from group $C$ died before the last day of measurements (21) and were omitted from further analysis.

Specimen collection. On day 0 (the day before treatment) and on days 7, 14, and 21, five mice in each of the four treatment groups were killed, which means that there was one set of 20 mice killed at day 7, another set of 20 mice killed at day 14 , and a final set of 20 mice killed at day 21. Mice were sacrificed by high-concentration carbon dioxide $\left(\mathrm{CO}_{2}\right)$. Peripheral blood was collected from the right femoral artery of each mouse before it was killed. These blood samples were spun at $3000 \mathrm{rpm}$ for 15 minutes, and then serum samples were collected and stored at $-80^{\circ} \mathrm{C}$. Primary tumors, TDLNs, spleens, and lungs were also collected. The diameter of the tumor was measured with vernier calipers (Fisher Scientific). Parts of the TDLNs and spleens were prepared for single-cell suspensions. Lymphocytes from spleens were separated with mouse lymphocyte separation medium (DKW33-R0100; EZSep). Primary tumors, lungs, and leftover parts of the TDLNs and spleens were fixed in $4 \%$ formalin for 6 hours and then embedded in paraffin wax.

Flow cytometry. Lymphocytes from TDLNs and spleens were resuspended in staining buffer (PBS containing 3\% fetal bovine serum) and stained for 30 minutes at $4^{\circ} \mathrm{C}$ with 
PerCP-conjugated anti-CD4 antibody, phycoerythrin-conjugated anti-CD25 antibody, phycoerythrin/Cy7-conjugated anti-CD8 antibody, and antigen-presenting cell-conjugated anti-CTLA-4 antibody (clones GK1.5, 3C7, 53-6.7, and $\mathrm{UC10}-4 \mathrm{~B} 9$, respectively; BioLegend) as well as their isotype control antibody (BioLegend) as a negative control. Foxp3 intracellular staining was performed on the cells stained with these antibodies. Cells were fixed and permeabilized using a fix/perm kit (eBioscience) according to the manufacturer's instructions and then labeled with Alexa Fluor 488-conjugated anti-Foxp3 antibody (clone MF-14; BioLegend) and its isotype control antibody (BioLegend) as a negative control. Flow cytometry was performed using a Becton Dickinson LSRII flow cytometer (BD Biosciences); $1 \times 10^{5}$ cells were acquired and data were analyzed using FlowJo software (BD Biosciences). To determine the percentage of $\mathrm{CD} 4^{+} \mathrm{CD} 25^{+} \mathrm{Foxp} 3^{+}$that were Tregs, lymphocytes were gated by plotting forward versus side scatter, followed by gating of the $\mathrm{CD} 4^{+}$population, the $\mathrm{CD} 25^{+}$ population, and the Foxp $3^{+}$population.

Immunohistochemical analysis and hematoxylin and eosin (H\&E) staining. Tissues were cut into $40-\mu \mathrm{m}$ sections, de-paraffinized in xylene, and rehydrated with graded ethanol. For antigen retrieval, the slides were steamed for 2.5 minutes in citrate buffer at $\mathrm{pH}$ 6.0. Immunohistochemistry was performed in one batch. Primary antibodies were obtained against CD4 (ab51312; Abcam, USA) at 1:50 dilution, CD8 (sc-7970; Santa Cruz Biotechnology, USA) at 1:250 dilution, Foxp3 (ab54501; Abcam, USA) at 1:100 dilution, and CTLA- 4 (bs-1179R; Bioss Inc, USA) at 1:250 dilution. The slides were incubated with primary antibodies overnight at $4^{\circ} \mathrm{C}$ and proteins were detected using an EnVision+ kit (DakoCytomation, USA). Tissues were stained with Mayer's H\&E using an automatic linear slide stainer (Shandon Varistain, Gemini, England). Stained microscopic specimens were evaluated for lung metastases and TDLN metastases by a pathologist who was blinded to the treatment groups. $\mathrm{CD} 4^{+}, \mathrm{CD}^{+}$, and CTLA- $4^{+}$cells were stained for brown membrane, and Foxp $3^{+}$Tregs were stained for brown nucleus. To count lymphocytes, the richest areas of lymphocytes identified at low magnification $(\times 100)$ were selected, and then positive $\mathrm{CD} 4^{+}, \mathrm{CD}^{+}, \mathrm{CTLA}-4^{+}$or Foxp $3^{+}$ lymphocytes were evaluated quantitatively by two independent observers who analyzed five $0.0625-\mathrm{mm}^{2}$ fields from these areas under a high-power $(\times 400)$ field using an Olympus confocal microscope (Center Valley, PA, USA). The results of these counts were then averaged.

Cytotoxicity assay in vitro. Lymphocytes from spleens and TDLNs (effector cells) were incubated with RM-1 prostate cancer cells (target cells). Cytotoxicity was tested with a standard 4-hour CytoTox 96 non-radioactive cytotoxicity assay (G1780; Promega, USA) with a 40:1 effector cell-to-target cell ratio according to the manufacturer's instructions.

Measurement of serum IL-2 and TGF- $\beta$ levels. Serum samples were collected from the peripheral blood of mice as described above. Serum IL-2 and TGF- $\beta$ levels were measured using mouse IL-2 (DKW12-2020-048; Dakewe Biotech Co.,
Ltd, China) and TGF- $\beta$ (DKW12-2710-096; Dakewe Biotech Co., Ltd, China) enzyme-linked immunosorbent assay (ELISA) kits to determine the concentration of these cytokines. These kits provide a reliable estimate of actual IL- 2 and TGF- $\beta$ levels in serum samples.

Statistical analysis. Statistical analyses were performed using the Statistical Package for Social Sciences (SPSS 16.0 for Windows; SPSS Inc., Chicago, IL). Differences in the number of cells at each time point and for each treatment group were compared using pairwise comparisons from the mixed effects analysis of variance (ANOVA) model. The log-rank test was used for overall survival analysis. Pearson's product-moment correlation coefficient $(R)$, which ranges from -1.00 to +1.00 , was used to calculate the correlation between Treg count and variables. $P<0.05$ was considered statistically significant. Data are representative of at least three independent experiments and are presented as means \pm standard deviation (SD).

\section{Results}

Cryoablation decreases intratumoral and TLDN Tregs and increases intratumoral and TLDN cytotoxic T lymphocytes (CTLs). Previous studies have shown that the primary role of Tregs is active suppression of several pathological and physiological immune responses in the host thus indicating that these cells contribute to the maintenance of immune homeostasis $[9,20,21]$. In the current study, we developed a prostate cancer mouse model to test the ability of cryoablation and anti-CTLA-4 antibody to generate sufficient ATIR to inhibit the tumor growth and system response. A main function of Tregs is suppression of the activation and expansion of naïve $\mathrm{T}$ cells, but they can also inhibit activated effector $\mathrm{T}$ cells and memory $\mathrm{CD}^{+}$and $\mathrm{CD} 8^{+} \mathrm{T}$ cells $[22,23]$. To assess changes in the number of Tregs and CTLs in primary tumors, spleens, and TDLNs after cryoablation therapy, we evaluated these tissues for counts of Foxp $3^{+}$Tregs, CTLA $-4^{+}$cells, CD $4^{+}$ $\mathrm{T}$ cells, and $\mathrm{CD}^{+} \mathrm{T}$ cells by immunohistochemistry on days $0,7,14$, and 21 after treatment.

On day 14, the number of intratumoral Foxp $3^{+}$Tregs was significantly lower in groups B and C than in group A (9.02 \pm 1.73 and $9.01 \pm 1.73$ cells vs. $14.57 \pm 1.09$ cells; $P=0.008$ for each comparison) (Fig. $1 \mathrm{Aa}, \mathrm{Ab}$, and $\mathrm{Ae}$ ). Intratumoral CTLA$4^{+}$cells exhibited the same pattern (Fig. $1 \mathrm{Ac}$, Ad, and Af). In contrast, for intratumoral $\mathrm{CD} 4^{+} \mathrm{T}$ cells and $\mathrm{CD} 8^{+} \mathrm{T}$ cells, on day 14 the number of cells in group B was significantly higher than that in group A $\left(\mathrm{CD} 4^{+} \mathrm{T}\right.$ cells: $36.12 \pm 0.95$ vs. $28.47 \pm$ 0.74 cells; $P=0.003$ and $\mathrm{CD} 8^{+} \mathrm{T}$ cells: $32.82 \pm 1.54$ vs. 26.47 \pm 0.74 cells; $P=0.002)$. Group $C$ had even greater cell counts (52.08 \pm 2.79 and $49.80 \pm 1.69$ cells; $P<0.001$ for both) (Fig. 1B). Also for $\mathrm{CD} 4^{+} \mathrm{T}$ cells and $\mathrm{CD} 8^{+} \mathrm{T}$ cells, the number of cells was significantly higher in group $\mathrm{D}$ than in group $\mathrm{A}$ on days 14 and 21, in group D than in group B on day 21, and in group $C$ than in group A on days 7, 14, and 21 (Fig. 1B). Similar changes were observed in TDLNs (Fig. 1C and 1D) and spleens (data not shown). Also, similar changes were 


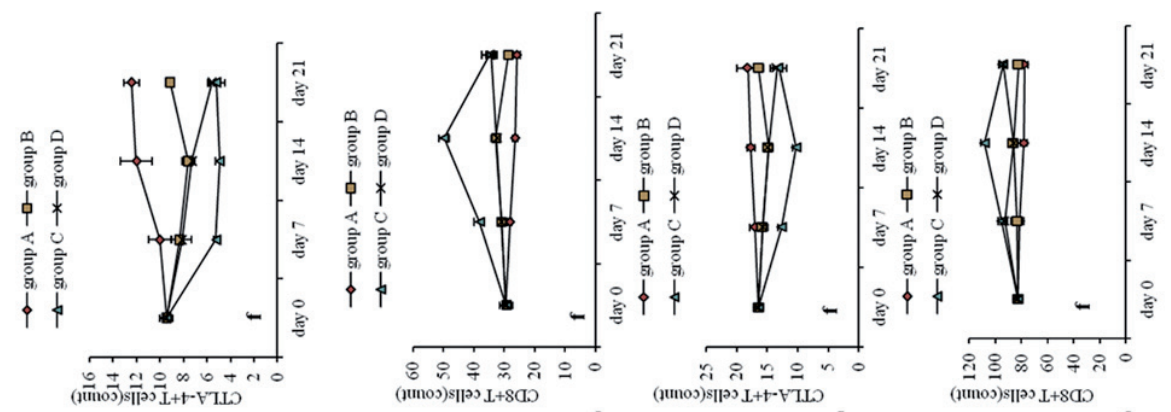

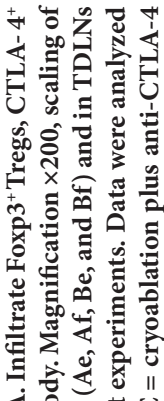

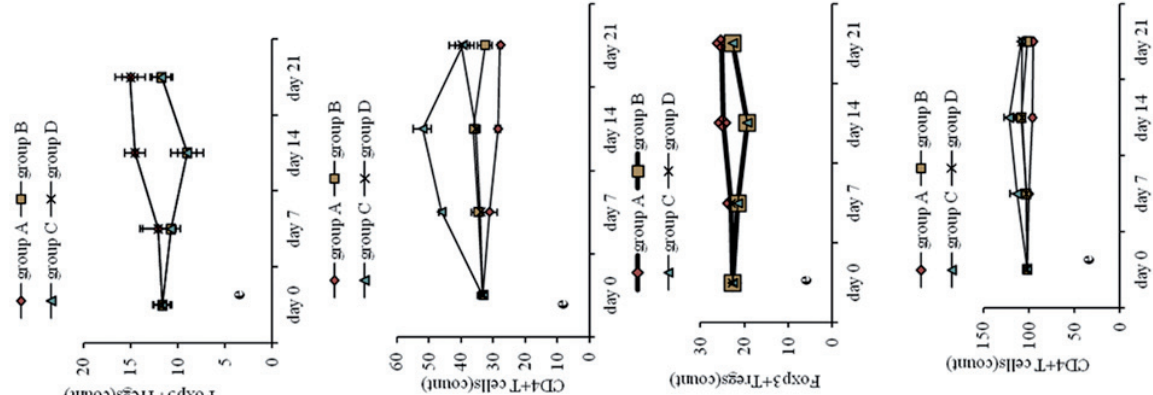

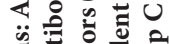

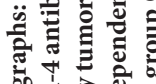

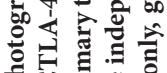

는

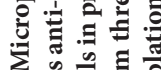

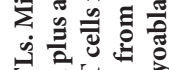

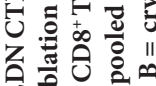

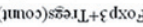
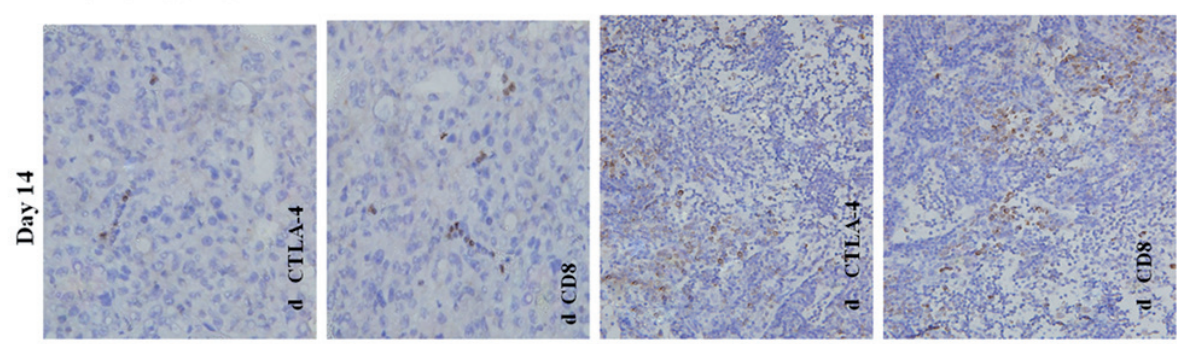

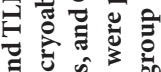

药

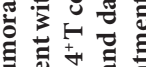

焉泀

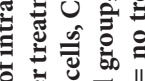

要击

言密出言
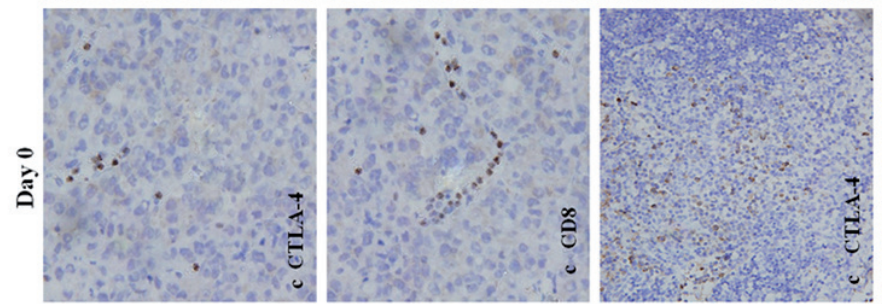

$\exists$

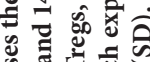

एँ

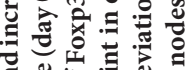

원

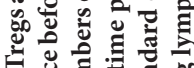

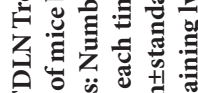
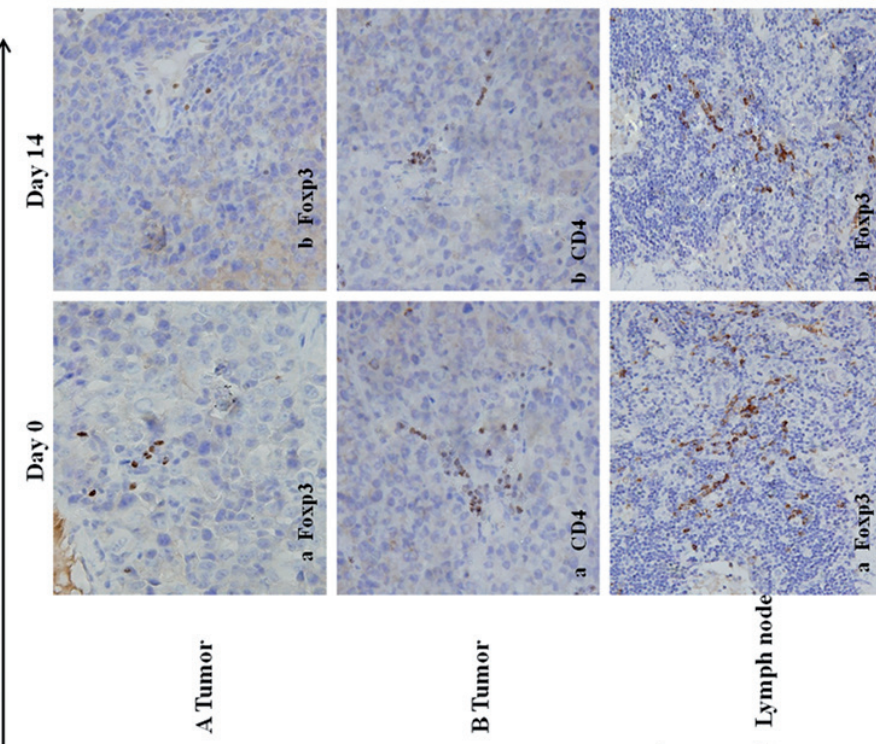

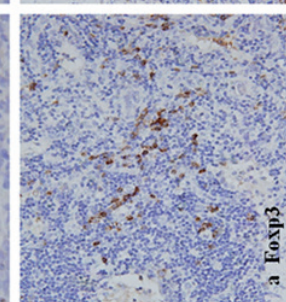

हั
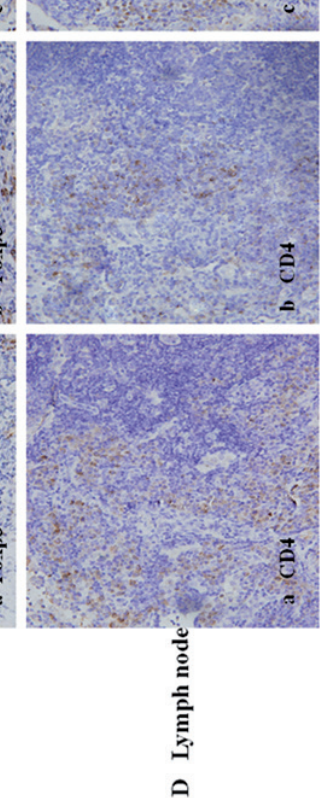

至

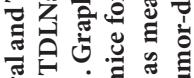

宣菏

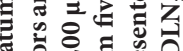

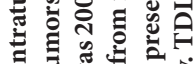

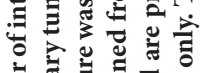

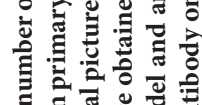

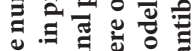

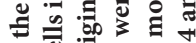

ष्ठ

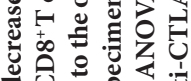

Oै की

完

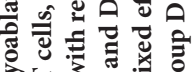

눙

نे

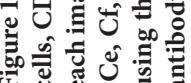


A

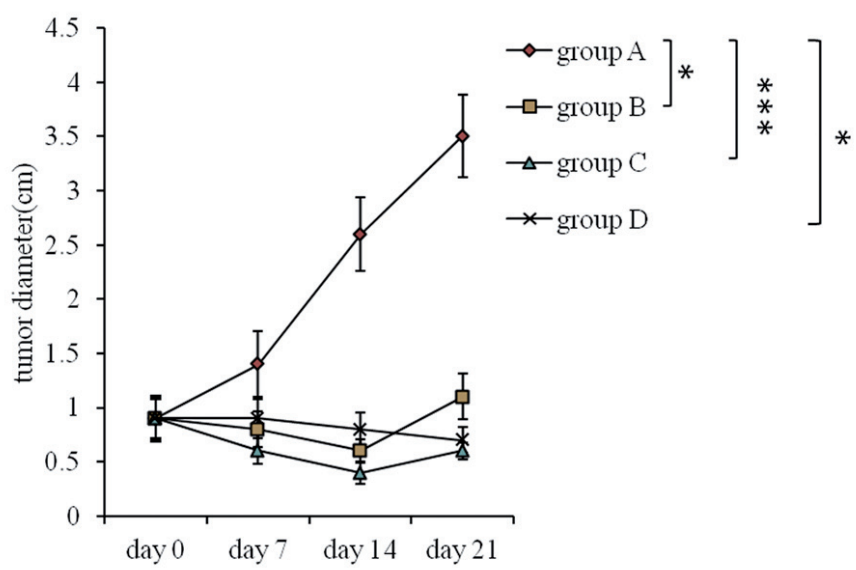

C

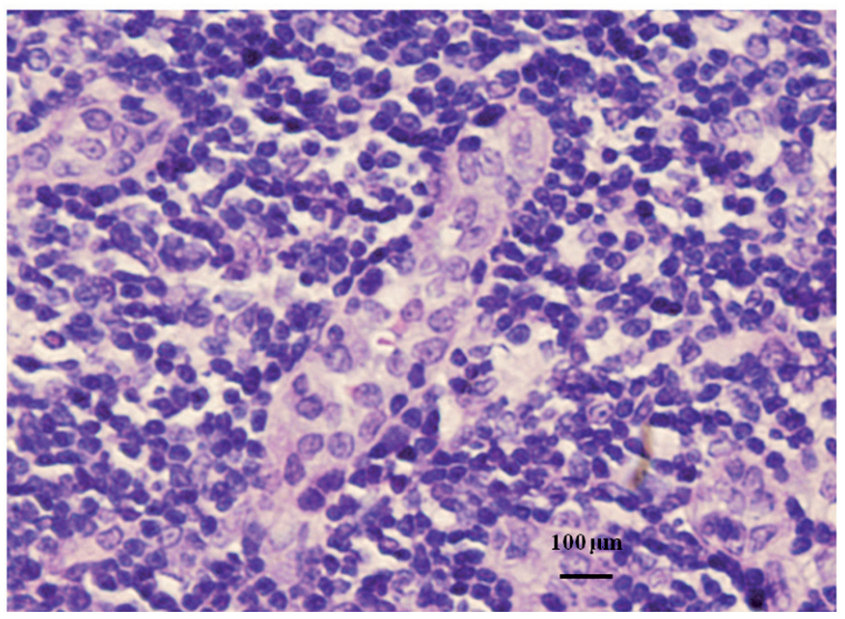

B

Overall survival rate

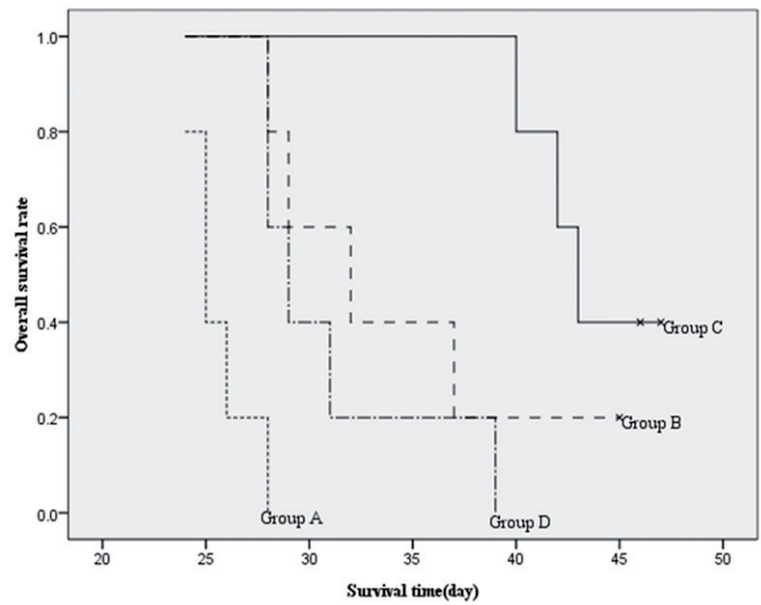

D

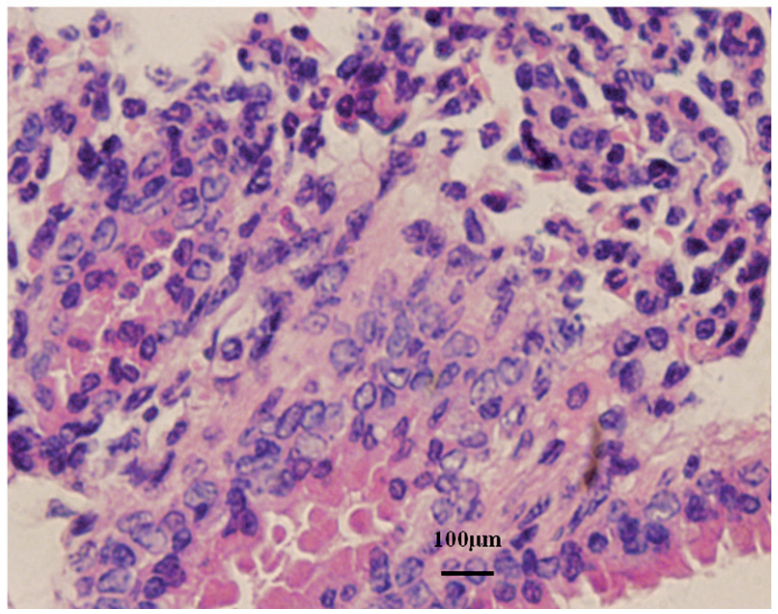

Figure 2. Cryoablation induced ATIR and anti-CTLA-4 antibody enhanced the effect. A. Tumor diameters of mice treated with cryoablation, antiCTLA-4 antibody, or both. Data are presented as mean \pm SD. Primary tumors of mice treated in group B or group D grew at a significantly lower rate compared with group $A$ on days 14 and 21. Differences between groups $C$ and $A$ were significant on days 7, 14, and 21. Specimens were obtained from five mice for each time point in each experimental group, and data were pooled from three independent experiments. Data were analyzed using the mixed effects ANOVA model and log-rank test and are presented as mean \pm SD. The following notations for $P$ value: ${ }^{*}, P=0.01-0.05 ;{ }^{* * *}, P<0.001$. B. Kaplan -Meier overall survival curves of mice. Group A versus group $B, P=0.045$; versus group $C, P<0.001$; versus group $D, P=0.348$. Group $B$ versus group $C, P=0.025$; versus group $D, P=0.828$. Group $C$ versus group $D, P=0.002$. Dotted line, group $A$. Dashed line, group $B$. Solid line, group $C$. Dash-dot line, group D. X, censored data. C. Representative example of TDLN metastasis (H\&E, $\times 400)$. D. Representative example of lung metastasis $(\mathrm{H} \& \mathrm{E}, \times 400)$. Group $\mathrm{A}=$ no treatment, group $\mathrm{B}=$ cryoablation only, group $\mathrm{C}=$ cryoablation plus anti-CTLA-4 antibody, group $\mathrm{D}=$ anti-CTLA-4 antibody only; TDLN, tumor-draining lymph nodes.

observed in TDLNs (Fig. 4) and spleens (data not shown) detected by flow cytometry. These results suggested that an immune response is induced by cryoablation (with or without anti-CTLA-4 antibody), indicating that a new balance of immune homeostasis was induced.

ATIR induced by cryoablation is enhanced by combination with anti-CTLA-4 therapy. To evaluate the inhibition of tumor growth after both cryoablation and anti-CTLA-4 antibody intervention therapy, we measured the primary tumor in each mouse at the largest diameter for up to 21 days.
Primary tumors of mice treated with only cryoablation (group B) or only anti-CTLA- 4 antibody (group D) were significantly smaller on days 14 and 21 compared with group $\mathrm{A}(P<0.05$ for all comparisons) (Fig. 2A). Combination therapy (group C) resulted in the smallest of primary tumors on days 7,14 , and 21; the differences between groups $\mathrm{C}$ and $\mathrm{A}$ were significant for these days ( $P<0.05$ for all comparisons). The only significant difference between groups B and D was observed on day 21 .

We then evaluated the effects of cryoablation and antiCTLA-4 antibody intervention therapy on distant metastasis. 
A

a
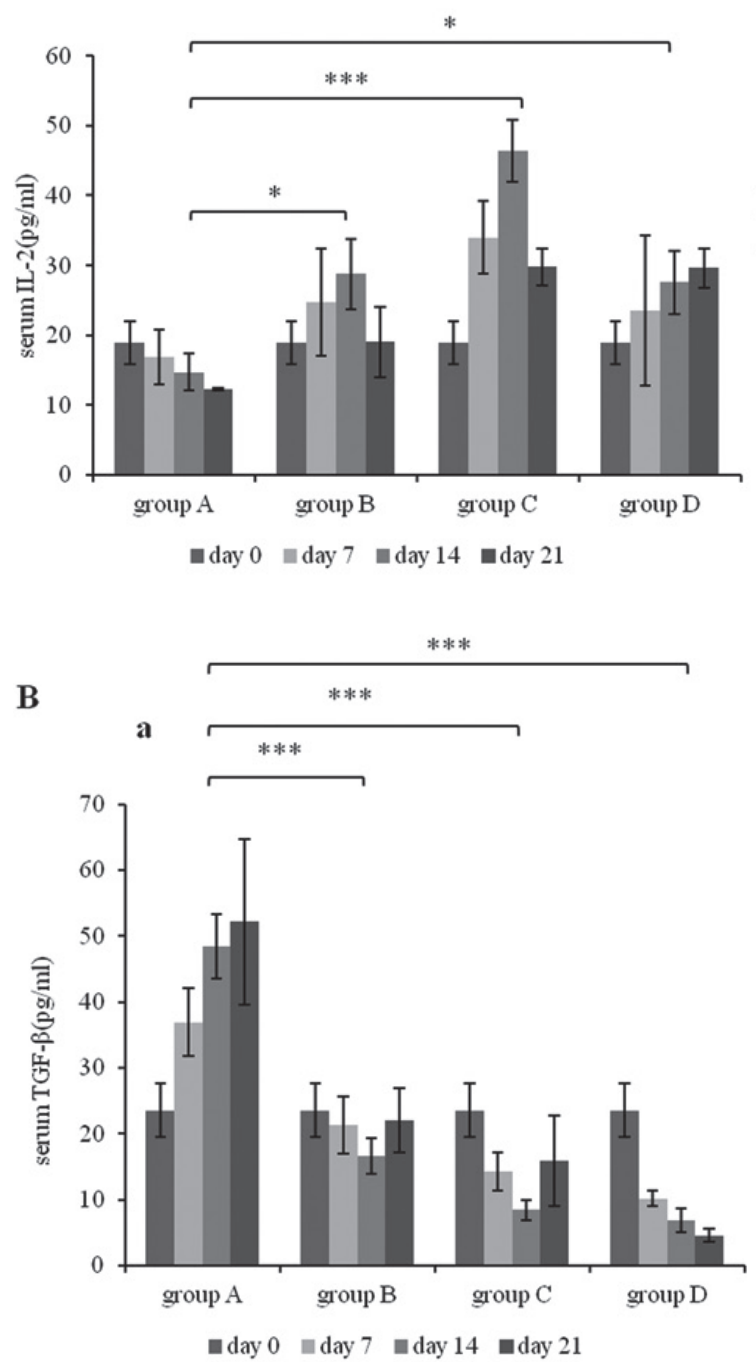

C

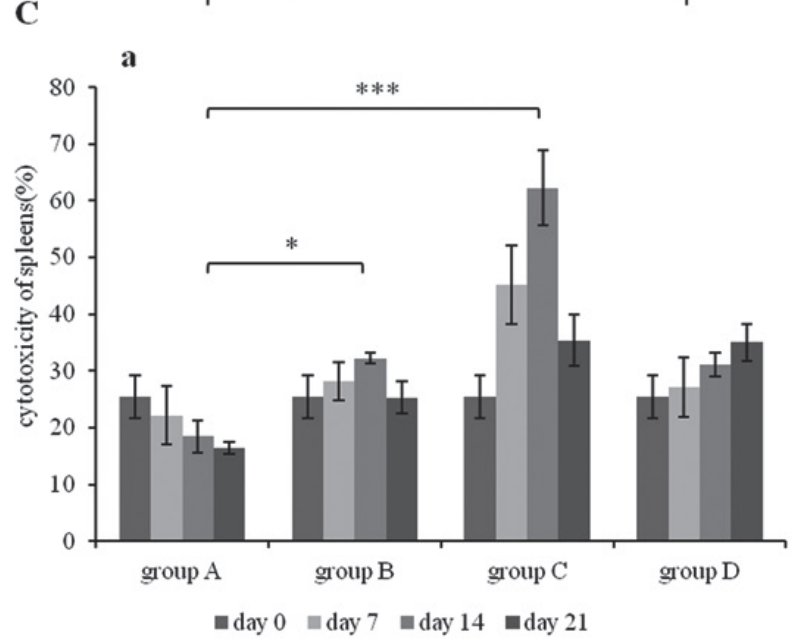

b
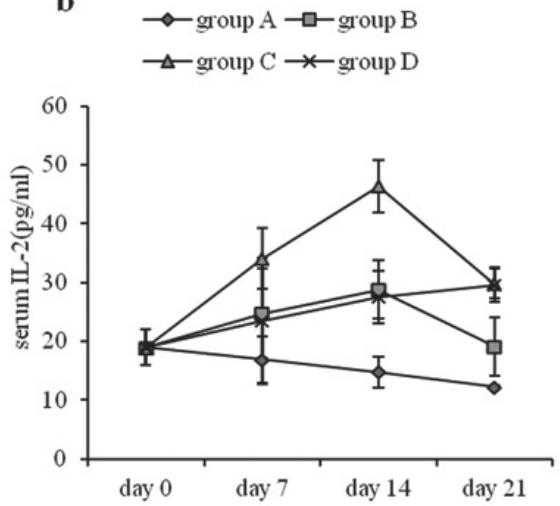

b $\rightarrow$ group $A \rightarrow \square-$ group $B$

$\triangle-$ group $\mathrm{C} \rightarrow$ group $\mathrm{D}$

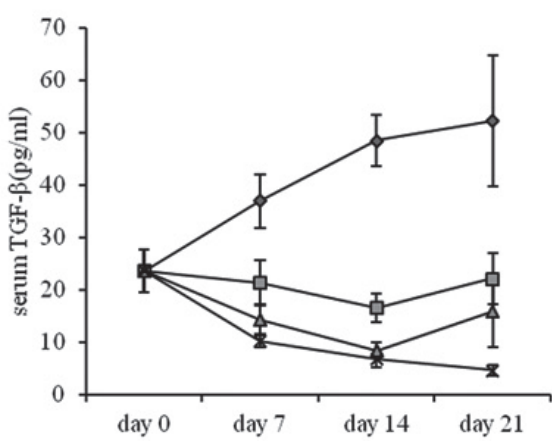

b
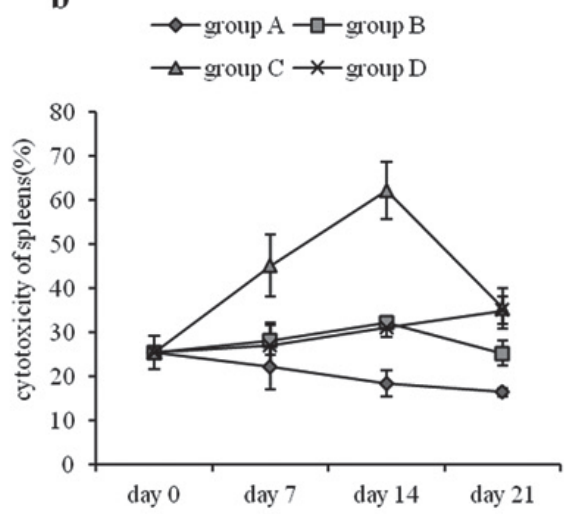


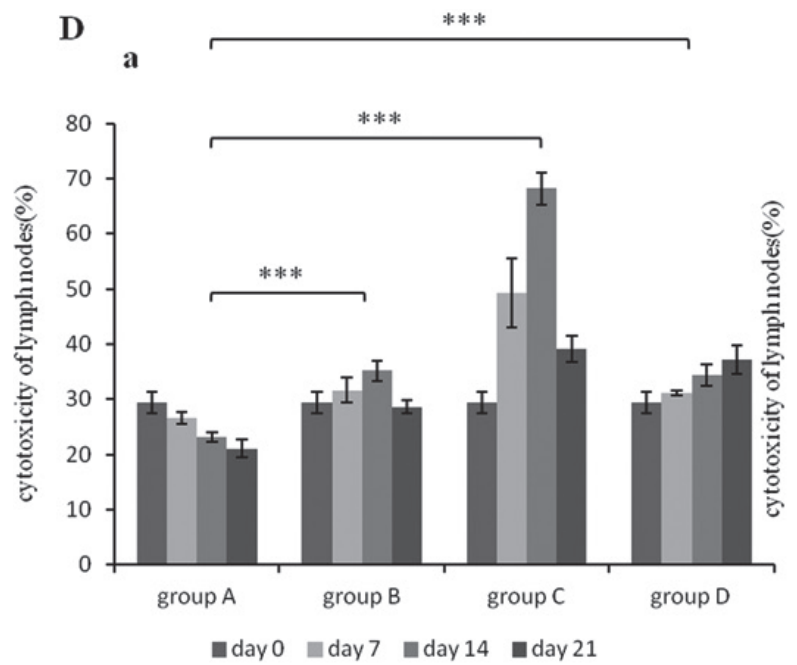

b

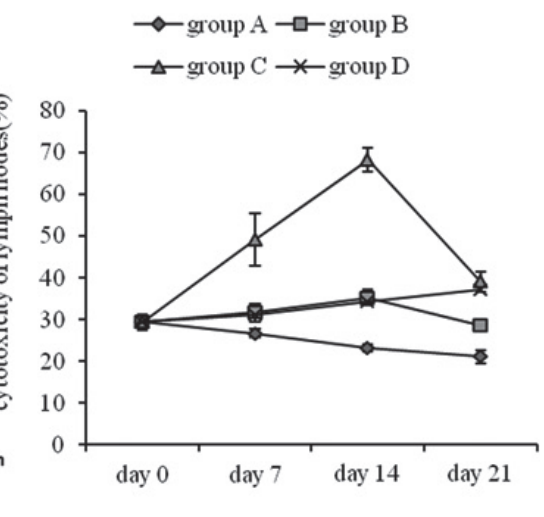

Figure 3. System response by measuring serum levels of the cytokines IL- 2 and TGF- $\beta$ and cytolytic activity against RM-1 prostate cancer cells in spleens and TDLNs. Serum IL-2 level variation between time points (Aa) and variation between groups (Ab), Serum TGF- $\beta$ level variation between time points $(\mathrm{Ba})$ and variation between groups $(\mathrm{Bb})$, cytotoxicity of lymphocytes from spleens (Ca, Cb) and TDLN (Da, Db) by incubating with RM-1 prostate cancer cells with an effecter cell to target cell ratio of 40:1. Specimens were obtained from five mice for each time point in each experimental group, and data were pooled from three independent experiments. Data were analyzed using the mixed effects ANOVA model and log-rank test and are presented as mean \pm SD. The following notations for $P$ value: ${ }^{\star}, P=0.01-0.05 ;{ }^{\star * \star}, P<0.001$. Group $\mathrm{A}=$ no treatment, group $\mathrm{B}=$ cryoablation only, group $\mathrm{C}=$ cryoablation plus anti-CTLA-4 antibody, group $\mathrm{D}=$ anti-CTLA-4 antibody only; TDLN, tumor-draining lymph nodes.

Combination therapy consistently resulted in the fewest cases of TDLN metastasis (Fig. 2C) and lung metastasis (Fig. 2D) (Table 1). Groups B and D each had fewer cases than group A did.

To assess the effect of the four interventions on overall survival, we observed another set of 20 mice until 45 days after therapy began. The survival rate was significantly higher in group $\mathrm{B}$ than in group $\mathrm{A}(P=0.045)$, in group $\mathrm{C}$ than in group $\mathrm{A}(P<0.001)$, in group $\mathrm{C}$ than in group $\mathrm{B}(P=0.025)$, and in group $\mathrm{C}$ than in group $\mathrm{D}(P=0.02)$ (Fig. $2 \mathrm{~B})$.

System response following cryoablation and CTLA-4 blockade. To our knowledge, one efficient way that Tregs can repress immune responses is by consuming IL-2, thereby killing effector cells $[24,25]$, although the role of IL-2 consumption by Tregs is controversial. Tregs can also produce high amounts of membrane-bound and soluble TGF- $\beta$, and blocking TGF- $\beta$ partially abrogates the suppression of T-cell proliferation in vitro with murine or human T cells $[26,27]$. Therefore, in the current study, we examined the system response by measuring serum levels of the cytokines IL-2 and TGF- $\beta$. We detected a significant increase of serum IL-2 level on day 14 in group B compared with group A (Fig. 3Aa and $\mathrm{Ab})(28.75 \pm 4.99$ and $14.73 \pm 2.71 \mathrm{pg} / \mathrm{ml}$, respectively; $P=0.019)$. Also, cryoablation plus anti-CTLA-4 antibody enhanced this effect $(46.40 \pm 4.45 \mathrm{pg} / \mathrm{ml}, P<0.001)$, which was also found in group D on days 14 and 21 compared with group A. A Significant difference between group B and group $\mathrm{D}$ was found only on day 21 , whereas significant differences were found between groups $\mathrm{C}$ and $\mathrm{A}$ on days 7, 14 and 21
Table 1. Number of mice with prostate cancer metastases in TDLNs and lungs in four treatment groups $(n=5$ mice per group per day)

\begin{tabular}{lcccc}
\hline $\begin{array}{l}\text { Metastasis site } \\
\text { and sampling day }\end{array}$ & Group A & Group B & Group C & Group D \\
\hline TDLN & 1 & 1 & 1 & 1 \\
Day 0 & 3 & 2 & 1 & 2 \\
Day 7 & 4 & 3 & 2 & 3 \\
Day 14 & 5 & 4 & 3 & 4 \\
Day 21 & & & & \\
Lung & 0 & 0 & 0 & 0 \\
Day 0 & 2 & 1 & 0 & 1 \\
Day 7 & 3 & 2 & 1 & 2 \\
Day 14 & 5 & 4 & 3 & 4 \\
Day 21 & & & & \\
\hline
\end{tabular}

Group $\mathrm{A}=$ no treatment, group $\mathrm{B}=$ cryoablation only, group $\mathrm{C}=$ cryoablation plus anti-CTLA-4 antibody, group $\mathrm{D}=$ anti-CTLA-4 antibody only; TDLN, tumor-draining lymph nodes.

(Fig.3Ab). This result was consistent with the relative decrease of infiltrated Tregs in tumor and lymph node compared with the control group.

We also found that the serum level of TGF- $\beta$ was significantly lower on day 14 in group B mice compared with group A mice (Fig. $3 \mathrm{Ba})(16.56 \pm 2.70$ and $48.47 \pm 4.84 \mathrm{pg} / \mathrm{ml}$, respectively; $P<0.001$ ), and cryoablation plus anti-CTLA4 antibody treatment also enhanced this effect $(8.40 \pm 1.54$ $\mathrm{pg} / \mathrm{ml}, P<0.001)$. Curiously enough, there was an obviously higher serum TGF- $\beta$ level in group $B$ than in both group $C$ and 

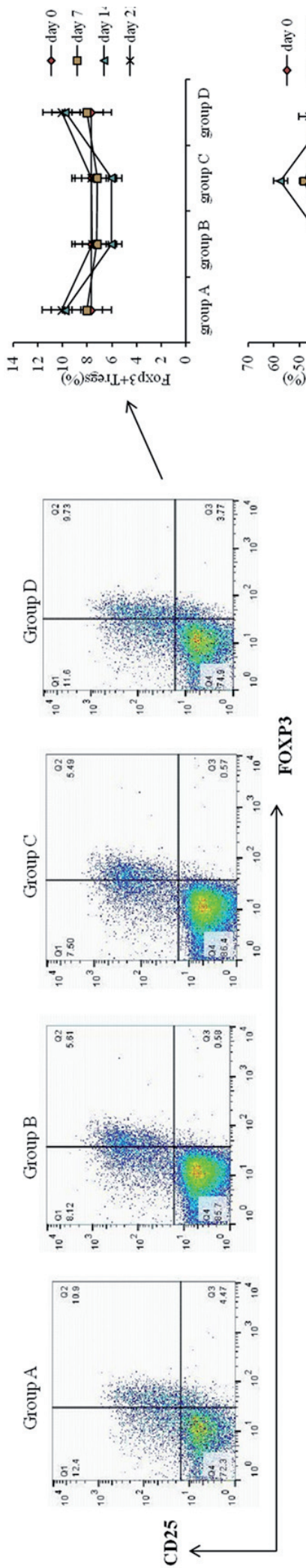

象
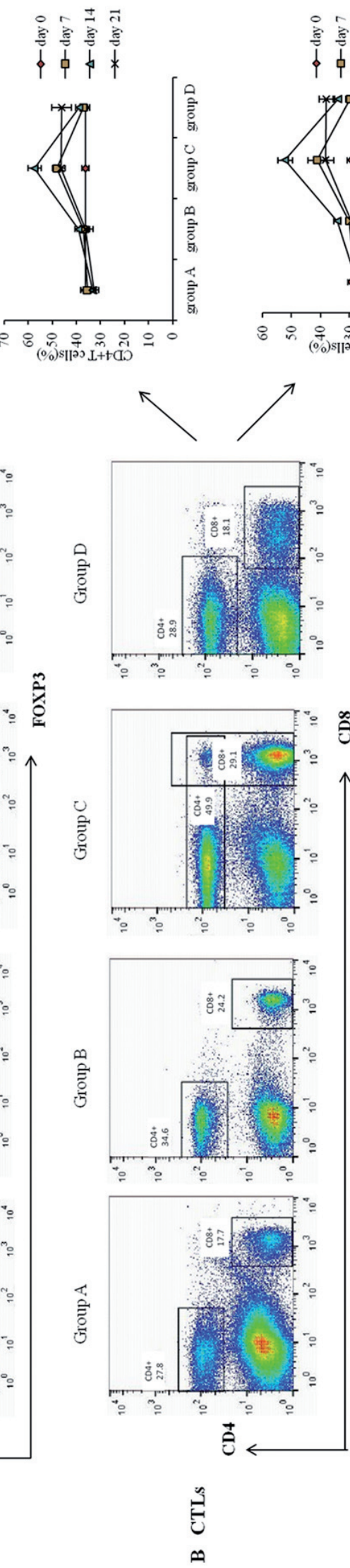

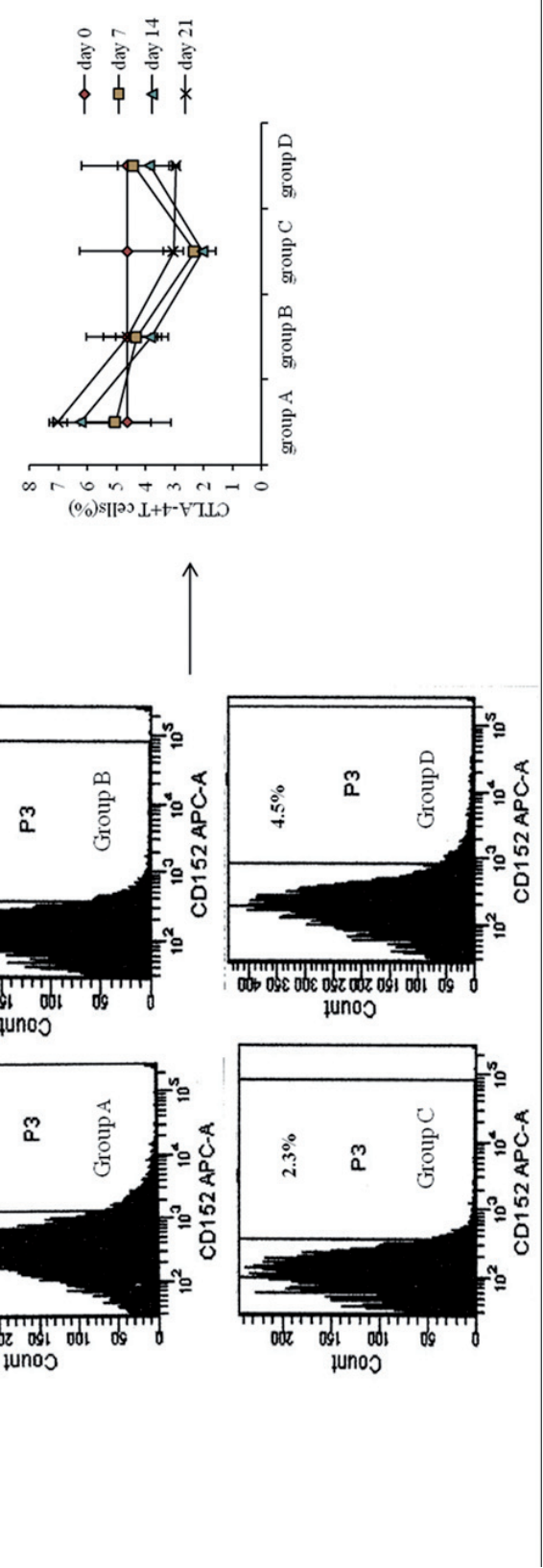

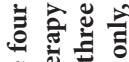

巳

$\Xi$ 政

政

这

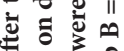

स

包

리의

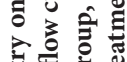

政

㱐。

ड人

产语

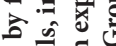

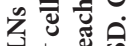

势系卉

콜

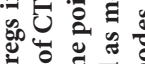

응

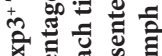

(屯)

की

نิ

掊 券

ठิ

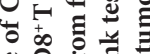

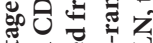

选

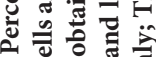

¿

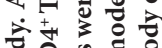

ㅇํ월

늘

政品

出 क

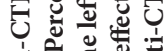

我舟

롱

零言言

政

สำ

它

苟

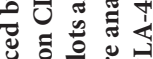

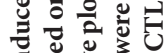

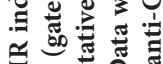

要

运을

ช

要

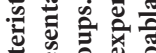

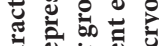

ड़

ปิ

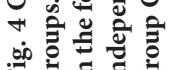


group $\mathrm{D}$ (Fig. $3 \mathrm{Ba}$ and $\mathrm{Bb}$ ). We presumed that cryoablation could induce the release of TGF- $\beta$ by leading to cell necrosis or releasing some special cytokines. Thus, the serum TGF- $\beta$ in group B comes from Treg production (influenced by cryoablation) as well as frozen stimulation, the serum TGF- $\beta$ in group $\mathrm{C}$ comes from Treg production (influenced by cryoablation and CTLA- 4 blockade) as well as frozen stimulation, whereas the serum TGF- $\beta$ in group D comes only from Treg production (influenced by CTLA- 4 blockade).

Also, in spleens and TDLNs of cryoablation-treated mice, we found strong cytolytic activity against RM-1 prostate cancer cells in vitro on day 14, as measured by cytotoxicity (Fig. 3Ca and $\mathrm{Da}$ ). Cryoablation plus anti-CTLA-4 antibody treatment also enhanced this cytolytic activity, seen on days 14 and 21 in group D compared with group A, whereas significant differences between groups B and D were found only on day 21 . Findings for days 7, 14 and 21 all significantly differed between groups $\mathrm{C}$ and $\mathrm{A}$ (Fig. $3 \mathrm{Ca}, \mathrm{Cb}, \mathrm{Da}$ and $\mathrm{Db}$ ). This result paralleled an increase of CTLs infiltrating primary tumors, spleens, and TDLNs. Therefore, these findings further verified the antitumor effects of cryoablation and anti-CTLA-4 antibody intervention therapy.

Characteristics of ATIR induced by cryoablation and anti-CTLA-4 antibody. At this point, we had found that the only significant difference in the antitumor effect between groups B and A was on day 14 after therapy had begun, yet group $\mathrm{C}$ had significant differences compared with groups $A$ and $B$ on days 7, 14 and 21. Moreover, group D showed obvious effects on days 14 and 21 compared with group A (Fig. 1, 2 and 3). The reasons of these discrepancies between different groups were unclear. Also, in the immunohistochemical analysis of TDLNs and intratumoral infiltration Foxp3+ Tregs, we did not find that the combination therapy in group $\mathrm{C}$ enhanced the effect of decreasing Treg number compared with group $\mathrm{B}$ instead of playing the same role as group B (Fig. 1Ae, Ce). This result was not consistent with the antitumor effect and the relative increase of CTL number in group $\mathrm{C}$ as described above. These unexpected findings prompted us to verify the nature of the antitumor effects induced by cryoablation and anti-CTLA-4 antibody intervention therapy.

To further investigate this characteristic of ATIR, parts of spleens and TDLNs were processed for single cells and were then separated and analyzed by flow cytometry. Populations of $\mathrm{CD} 8+$ and $\mathrm{CD} 4+\mathrm{T}$ cells were found after gating on viable lymphocytes. Gating on $\mathrm{CD} 4^{+}$cells and analyzing for the expression of CD25 and Foxp3, we found that $\mathrm{CD} 4^{+} \mathrm{CD} 25^{+} \mathrm{Foxp} 3^{+}$ cells were enriched in group $\mathrm{A}$. There were also significant differences in the Foxp $3^{+}$Treg numbers between both in group $\mathrm{B}$, group C compared with group A only on day 14, but the combination therapy (group C) did not enhance the change in numbers of infiltration Foxp $3^{+}$Tregs in primary tumors and TDLNs compared with group A, and there was no significant difference between group $\mathrm{D}$ and group $\mathrm{A}$ at any time point (Fig.4A). Additionally, CTLA- $4^{+}$cells had different changes compared with Foxp $3^{+}$Tregs (Fig. 4C). Differently, the group
$\mathrm{C}$ combination therapy further enhanced these changes in CTL number, which had significant differences compared with both group A and group B on days 7, 14 and 21. Group D showed obvious effects on days 14 and 21 compared with group $\mathrm{A}$, which was consistent with the antitumor effect we showed above (Fig. 4B). This phenomenon indicated that cryoablation induced ATIR through decreasing Treg numbers while the anti-CTLA- 4 antibody did not. The decrease of Treg number induced by cryoablation reached its lowest level on day 14 but then returned to the preoperative levels on day 21, which indicated that the ATIR induced by cryoablation was time-dependent. Considering that the anti-CTLA-4 antibody did not cause a change in Treg number but still showed an antitumor effect in group $\mathrm{D}$, we presumed that the ATIR induced by anti-CTLA- 4 antibody might be achieved mainly through influencing Treg function. Therefore, we analyzed the ratios of Foxp3 ${ }^{+}$Treg/ $\mathrm{CD}^{+} \mathrm{T}$ cells in TDLNs, primary tumors and spleens of the 4 groups. As shown in Fig. 5 (A, B, C and D), we found that the ratios of Foxp $3^{+}$Treg/ $\mathrm{CD} 8^{+} \mathrm{T}$ cells in both group $\mathrm{C}$ and group $\mathrm{D}$ had significant differences compared with both group A and group B on day 14 and day $21(P<0.05)$, and there is no significant difference between group $A$ and group B $(P>0.05)$. These results were consistent with our hypothesis above. Previous studies demonstrated the importance of CTLA-4 in the Treg-mediated T-cell suppression process $[14,16,28-30]$. This role of CTLA-4 in the suppression function of Tregs may also explain the effect of influencing Tregs function by CTLA- 4 blockade in our study. In addition, we did not find that the ATIR induced by anti-CTLA- 4 antibody is time dependent (Fig.1, 3 and 4) as there still was obvious ATIR on day 21 in group D.

Correlation analysis between intratumoral Tregs and changes in CTL counts, CTL tumor-specific cytotoxicity, and serum IL- 2 and TGF- $\beta$ levels. Finally, we determined the

Table 2. Pearson's product-moment correlation coefficient analysis between intratumoral infiltration Treg count of $9.13 \pm 2.82$ and CTL count or percentage

\begin{tabular}{lcc}
\hline CTL type and site & Mean \pm SD (No. or \%) & $R$ value \\
\hline CD4 $^{+}$ & $38.46 \pm 6.96$ & -0.844 \\
Tumor (count) & $73.69 \pm 8.04$ & -0.854 \\
Spleen (count) & $36.09 \pm 4.95$ & -0.814 \\
Spleen (\%) & $107.65 \pm 7.28$ & -0.767 \\
TDLN (count) & $42.12 \pm 7.66$ & -0.837 \\
TDLN (\%) & & \\
CD8 ${ }^{+}$ & $34.28 \pm 6.88$ & -0.806 \\
Tumor (count) & $57.75 \pm 8.56$ & -0.833 \\
Spleen (count) & $28.97 \pm 5.65$ & -0.827 \\
Spleen (\%) & $89.38 \pm 9.21$ & -0.854 \\
TDLN (count) & $35.44 \pm 8.00$ & -0.891 \\
TDLN (\%) & & \\
\hline
\end{tabular}

$P<0.001$ for intratumoral infiltration Treg count $9.13 \pm 2.82$ and each CTL type and site.

Data are presented as mean \pm standard deviation (SD). 
A

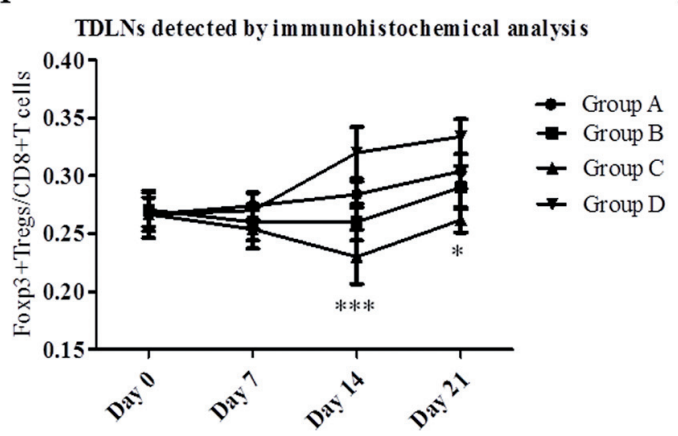

C
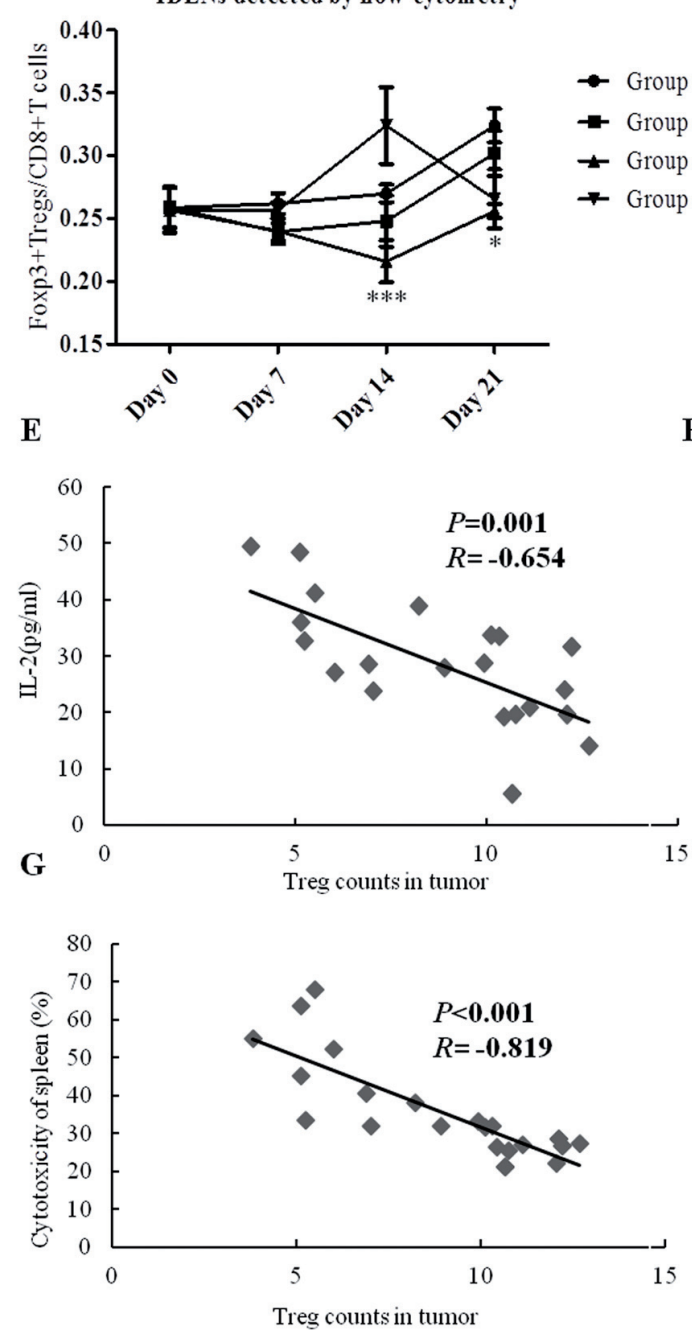

B

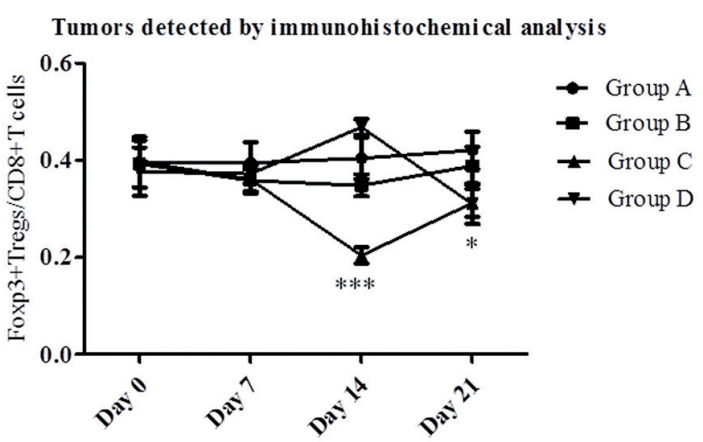

D
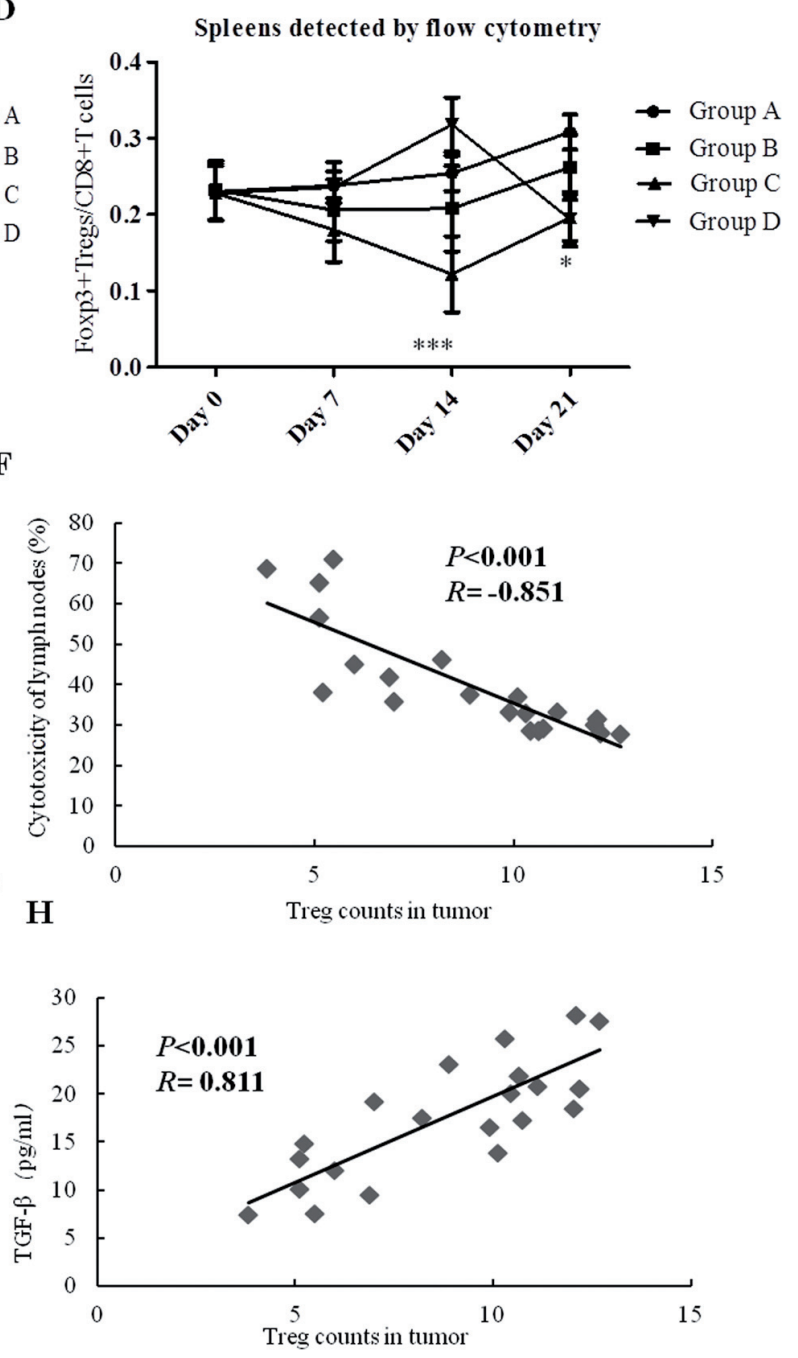

Figure 5. Ratios of Treg/CD8+ T cells in 4 groups and Correlation analysis between intratumoral Tregs and changes in CTL counts, CTL tumor-specific cytotoxicity, and serum IL-2 and TGF- $\beta$ levels. A and B. Foxp3 ${ }^{+}$Treg $/ \mathrm{CDB}^{+}$T cells of four groups in TDLNs (A) and primary tumors (B) detected by immunohistochemical analysis. C and D. Foxp $3^{+}$Treg/CD8 ${ }^{+} \mathrm{T}$ cells of four groups in TDLNs (C) and spleens (D) detected by flow cytometry. E. Negative correlation between intratumoral Tregs number and serum IL-2 levels $(R=-0.654, P=0.001)$. F. Negative correlation between intratumoral Tregs number and CTLs special cytotoxicity of draining lymph nodes $(R=-0.851, P<0.001)$. G. Negative correlation between intratumoral Tregs number and CTLs special cytotoxicity of spleens $(R=-0.819, P<0.001)$. H. Positive correlation between intratumoral Tregs number and serum TGF- $\beta$ level. $(R=$ $0.811, P<0.001)$. Specimens were obtained from five mice for each time point in each experimental group, and data were pooled from three independent experiments. Pearson's product-moment correlation coefficient $(R)$, which ranges between -1.00 and +1.00 , was used to calculate the correlation between two variables. The following notations for $P$ value: ${ }^{*}, P=0.01-0.05 ;{ }^{* *}, P<0.001$. Group $A=$ no treatment, group $B=$ cryoablation only, group $\mathrm{C}=$ cryoablation plus anti-CTLA- 4 antibody, group $\mathrm{D}=$ anti-CTLA- 4 antibody only; TDLN, tumor-draining lymph nodes. 
correlation between Treg count and variables using Pearson's product-moment correlation coefficient $(R)$. The intratumoral Treg number was significantly negatively correlated with both $\mathrm{CD}^{+}$and $\mathrm{CD} 8^{+} \mathrm{T}$ cells number or percentage at all sites (primary tumors, spleens, and TDLNs) $(P<0.001$ for each correlation) (Table 2). The intratumoral Treg number was also significantly negatively correlated with serum IL-2 level (Fig. 5E) and with CTL cytotoxicity in TDLNs (Fig. 5F) and in spleens (Fig. 5G) $(P<0.001$ for each correlation). Thus, these variables increased as the Treg number decreased. In addition, a significant positive correlation between intratumoral Treg number and serum TGF- $\beta$ level was found (Fig. $5 \mathrm{H}, P<0.001$ ); this result indicates that Tregs can produce high amounts of TGF- $\beta$ [26-27]. These correlation analyses confirmed our earlier results.

\section{Discussion}

Cryoablation destroys tumor tissue and releases tumor antigens that may help activate tumor-specific $T$ cells to induce an ATIR. However, studies of animal models and human subjects have revealed either weak or absent immune responses after cryoablation [31]. In addition, significant objective clinical response rates have been low, although evidence exists for the induction of tumor-specific T-cell responses to immunotherapy [32]. Further experimental studies are needed to understand the effects of cryoablation and immunotherapy. Here, we investigated the characteristics of the ATIR after cryoablation and whether anti-CTLA- 4 antibody can enhance the effect of tumor cryoablation.

Our results are not only consistent with a recent report showing that the combination of cryoablation and CTLA-4 blockade augmented the ATIR and rejection of tumor metastases in their setting [19], but also reveal characteristics of the ATIR induced by this combination therapy in prostate cancer. On the one hand, cryoablation induced the ATIR by decreasing the number of Tregs, as we confirmed by immunohistochemical staining of tumor tissues and analyzing spleens and TDLNs by flow cytometry. On the other hand, the ATIR induced by anti-CTLA- 4 antibody did not significantly alter the number of Tregs and may instead influence Treg function and activation, which is consistent with results from previous studies [30, 33].

An important finding of our study was that the number of Tregs induced by cryoablation were lowest on day 14 and returned to preoperative levels on day 21 , indicating that the ATIR induced by cryoablation is time dependent and the ATIR caused by cryoablation is also time dependent. This finding suggests the appropriate clinical treatment interval between cryoablations. It also implies that cryoablation should be used repeatedly at these intervals to maintain the antitumor effects. Anti-CTLA-4 antibody therapy did not induce timedependent ATIR.

Our study is the first to show that cryoablation can induce the release of TGF- $\beta$. TGF- $\beta$ release may occur due to necrotic cell stimulation or the release of cytokines indirectly. Further research is needed to determine the release mechanism. To our knowledge, we are also the first group to use cytotoxic assays to determine changes in lymphocyte populations after treatment with cryoablation and anti-CTLA-4 antibody and to demonstrate an augmented and specific immune response with these treatment modalities against RM-1 prostate cancer cells.

Finally, we discovered that the intratumoral Treg count and CTL counts and percentages are negatively correlated. When the number of Tregs decreased, the number of $\mathrm{CD} 4^{+} \mathrm{T}$ cells and $\mathrm{CD}^{+} \mathrm{T}$ cells increased, which suggests that immune responses to prostate cancer after cryoablation occur in vivo. This observation is consistent with previous studies demonstrating that activated effector T cells and memory $\mathrm{CD} 4^{+}$cells and $\mathrm{CD} 8^{+}$ $\mathrm{T}$ cells can be inhibited by Tregs [22-23]. Therefore, cryoablation might be used to manipulate Treg-suppressive functions as well as effector $\mathrm{T}$ cells, thereby establishing a new balance between these cell types.

Our findings raise the following question: What is the mechanism that allows cryoablation to alter Tregs in the prostate tumor microenvironment? The process may involve sequential events. The tumor cells or some secreted chemokines inside the tumor may attract Tregs to migrate into the tumor, but after cryoablation, most tumor cells are dying and the secretion of chemokines decreases. It is likely that the release of cellular antigens and cytokines, such as TGF- $\beta$, by cell destruction leads to activation of antigen-presenting cells. Further studies are needed to better define the tumor immunosuppressive mechanisms induced by cryoablation and to design more vigorous and effective combinatorial strategies for generating productive immune responses.

In conclusion, our results imply that cryoablation induces an ATIR and that anti-CTLA- 4 antibody injection therapy enhances the effect of cryoablation to reduce distant metastases. ATIR induced by cryoablation was achieved by a time-dependent reduction in the number of Tregs, whereas the ATIR induced by anti-CTLA- 4 antibody might be achieved mainly through influencing Treg function or activation. Anti-CTLA-4 antibody treatment maintained its effect through day 21 after therapy and was not time dependent. Hence, the use of repeat cryoablation plus anti-CTLA-4 antibody should maintain very high antitumor response effects. We also suggest that strategies that combine Treg depletion with cryoablation may be an effective means of improving immunotherapeutic outcomes for prostate cancer.

Acknowledgments: Thanks to Elizabeth Lizzie Hess and Michael Worley of the University of Texas M.D. Anderson Cancer Center for critical reading of the manuscript. This work was supported in part by the National Natural Science Foundation of China (No. 81001002, 30973438, 81101754 and 81201861), Tianjin Natural Science Foundation (No. 09JCYBJC10400), Tianjin Health Bureau Foundation (No. 2010KZ7) and MD Anderson's Cancer Center Support Grant (CCSG) (CA016672). 


\section{References}

[1] JEMAL A, SIEGEL R, WARD E, MURRAY T, XU J et al. Cancer statistics, 2006. CA Cancer J Clin 2006; 56: 106-30. http://dx.doi.org/10.3322/canjclin.56.2.106

[2] ARLEN PM, GULLEY JL THERAPEUTIC VACCINES FOR PROSTATE CANCER: A REVIEW OF CLINICAL DATA. Curr Opin Investig Drugs 2005; 6: 592-596.

[3] BAHN DK, LEE F, BADALAMENT R, KUMAR A, GRESKI $\mathrm{J}$ et al. Targeted cryoablation of the prostate: 7-year outcomes in the primary treatment of prostate cancer. Urology 2002; 60: 3-11. http://dx.doi.org/10.1016/S0090-4295(02)01678-3

[4] ABLIN RJ CRYOIMMUNOTHERAPY. Br Med J 1972; 3: 476.

[5] SIDANA A, CHOWDHURY WH, FUCHS EJ, RODRIGUEZ R CRYOIMMUNOTHERAPY IN UROLOGIC ONCOLOGY. Urology 2010; 75: 1009-14. http://dx.doi. org/10.1016/j.urology.2009.06.020

[6] LI Y, GUO Z, LIU CF, XING WG, SI TG et al. Effect of transcatheter renal arterial embolization combined with cryoablation on regulatory CD4+ CD25+ T lymphocytes in the peripheral blood of patients with advanced renal carcinoma. Cryobiology 2012; 65: 56-59. http://dx.doi.org/10.1016/ j.cryobiol.2012.04.002

[7] SABEL MS, NEHS MA, SU G, LOWLER KP, FERRARA JL et al. Immunologic response to cryoablation of breast cancer. Breast Cancer Res Treat 2005; 90: 97-104. http://dx.doi. org/10.1007/s10549-004-3289-1

[8] SABEL MS, ARORA A, SU G, CHANG AE Adoptive immunotherapy of breast cancer with lymph node cells primed by cryoablation of the primary tumor. Cryobiology 2006; 53: 360 6, 2006. http://dx.doi.org/10.1016/j.cryobiol.2006.07.004

[9] SAKAGUCHI S Naturally arising CD4 + regulatory t cells for immunologic self-tolerance and negative control of immune responses. Annu Rev Immunol 2004; 22: 531-562. http:// dx.doi.org/10.1146/annurev.immunol.21.120601.141122

[10] ZOU W Regulatory T cells, tumour immunity and immunotherapy. Nat Rev Immunol 2006; 6: 295-307. http://dx.doi. org/10.1038/nri1806

[11] CURIEL TJ Regulatory T cells and treatment of cancer. Curr Opin Immunol 2008; 20: 241-246. http://dx.doi.org/10.1016/ j.coi.2008.04.008

[12] BACCHETTA R, GAMBINERI E, RONCAROLO MG Role of regulatory T cells and FOXP3 in human diseases. J Allergy Clin Immunol 2007; 120: 227-235. http://dx.doi.org/10.1016/ j.jaci.2007.06.023

[13] SCHMIDT A, OBERLE N, KRAMMER PH Molecular mechanisms of Treg-mediated T cell suppression. Front Immunol 2012; 3: 51. http://dx.doi.org/10.3389/fimmu.2012.00051

[14] TAKAHASHI T, TAGAMI T, YAMAZAKI S, UEDE T, SHIMIZU J et al. Immunologic self-tolerance maintained by $\mathrm{CD} 25(+) \mathrm{CD} 4(+)$ regulatory $\mathrm{T}$ cells constitutively expressing cytotoxicity T lymphocyte-associated antigen 4. J Exp Med 2000; 192: 303-310. http://dx.doi.org/10.1084/ jem.192.2.303

[15] DIECKMANN D, PLOTTNERL H, BERCHTOLD S, BERGER T, SCHULER G Ex vivo isolation and characterization of $\mathrm{CD} 4(+) \mathrm{CD} 25(+) \mathrm{T}$ cells with regulatory properties from hu- man blood. J Exp Med 2001; 193: 1303-1310. http://dx.doi. org/10.1084/jem.193.11.1303

[16] TANG Q, BODEN EK, HENRIKSEN KJ, BOUR JORDAN $\mathrm{H}, \mathrm{BI} \mathrm{M}$ et al. Distinct roles of CTLA-4 and TGF-beta in CD4+CD25+ regulatory T cell function. Eur J Immunol 2004; 34: 2996-3005. http://dx.doi.org/10.1002/eji.200425143

[17] THORNTON AM, DONOVAN EE, PICCIRILLO CA, SHEVACH EM Cutting edge: IL-2 is critically required for the in vitro activation of $\mathrm{CD} 4+\mathrm{CD} 25+\mathrm{T}$ cell suppressor function. J Immunol 2004; 172: 6519-6523. http://dx.doi.org/10.4049/ jimmunol.172.11.6519

[18] ZHOU L, FU JL, LU YY, FU BY, WANG CP et al. Regulatory $T$ cells are associated with post-cryoablation prognosis in patients with hepatitis B virus-related hepatocellular carcinoma. J Gastroenterol 2010; 45: 968-978. http://dx.doi.org/10.1007/ s00535-010-0243-3

[19] WAITZR, SOLOMON SB, PETRE EN, TRUMBLE AE, FASSO $\mathrm{M}$ et al. Potent Induction of Tumor Immunity by Combining Tumor Cryoablation with Anti-CTLA-4 therapy. Cancer Res 2012; 72: 430-9. http://dx.doi.org/10.1158/0008-5472.CAN$\underline{11-1782}$

[20] SAKAGUCHI S Regulatory T cells: key controllers of immunologic self-tolerance. Cell 2000; 101: 455-458.

[21] SAKAGUCHI S, SETOGUCHI R, YAGI H, NOMURA T Naturally arising Foxp3-expressing CD25(+)CD4(+) regulatory $\mathrm{T}$ cells in self-tolerance and autoimmune disease. Curr Top Microbiol Immunol 2006; 305: 51-66. http://dx.doi. org/10.1007/3-540-29714-6 3

[22] LEVINGS MK, SANGREGORIO R, RONCAROLO MG Human $\mathrm{cd} 25(+) \mathrm{cd} 4(+) \mathrm{t}$ regulatory cells suppress naive and memory $\mathrm{T}$ cell proliferation and can be expanded in vitro without loss of function. J Exp Med 2001; 193: 1295-1302. http://dx.doi.org/10.1084/jem.193.11.1295

[23] SUVAS S, KUMARAGURU U, PACK CD, LEE S, ROUSE BT CD4+CD25+T cells regulate virus-specific primary and memory CD8+T cell responses. J Exp Med 2003; 198: 889-901. http://dx.doi.org/10.1084/jem.20030171

[24] PANDIYAN P, ZHENG L, ISHIHARA S, REED J, LENARDO MJ CD4+CD25+Foxp3+ regulatory T cells induce cytokine deprivation-mediated apoptosis of effector CD4+T cells. Nat Immunol 2007; 8: 1353-1362. http://dx.doi.org/10.1038/ $\underline{\text { ni1536 }}$

[25] PANDIYAN P, CONTI HR, ZHENG L, PETERSON AC, MATHEM DR et al. CD4(+)CD25(+)Foxp3(+)regulatory T cells promote Th17 cells in vitro and enhance host resistance in mouse Candida albicans Th17 cell infection model. Immunity 2011; 34: 422-434. http://dx.doi.org/10.1016

[26] LEVINGSMK, SANGREGORIOR, SARTIRANA C, MOSCHIN AL, BATTAGLIA M et al. Human CD25+CD4 + T suppressor cell clones produce transforming growth factor $\beta$, but not interleukin 10, and are distinct fromtype1T regulatory cells. J Exp Med 2002; 196: 1335-1346. http://dx.doi.org/10.1084/jem.20021139

[27] NAKAMURA K, KITANI A, FUSS I, PEDERSEN A, HARADA $\mathrm{N}$ et al. TGF- $\beta 1$ plays an important role in the mechanism of CD4+CD25+ regulatory $\mathrm{T}$ cell activity in both humans and mice. J Immunol 2004; 172: 834-842. http://dx.doi. org/10.4049/jimmunol.172.2.834 
[28] ODERUP C, CEDERBOM L, MAKOWSKA A, CILIO CM, IVARA F Cytotoxic T lymphocyte antigen-4-dependent down-modulation of cost imulatory molecules on dendritic cells in CD4+CD25+regulatory T-cell-mediated suppression. Immunology 2006; 118: 240-249. http://dx.doi.org/10.1111/ j.1365-2567.2006.02362.x

[29] ONISHI Y, FEHERVARI Z, YAMAGUCHI T, SAKAGUCHI $S$ Foxp3 + natural regulatory $\mathrm{T}$ cells preferentially form aggregates on dendritic cells in vitro and actively inhibit their maturation. Proc Natl Acad Sci USA 2008; 105: 10113-8. http://dx.doi.org/10.1073/pnas.0711106105

[30] WING K, ONISHI Y, PRIETO MARTIN P, YAMAGUCHI T, MIYARA $\mathrm{M}$ et al. CTLA-4 control over Foxp3+ regulatory
T cell function. Science 2008; 322: 271-275. http://dx.doi. org/10.1126/science. 1160062

[31] SABEL MS CRYO-IMMUNOLOGY: a review of the literature and proposed mechanisms for stimulatory versus suppressive immune responses. Cryobiology 2009; 58: 1-11. http://dx.doi. org/10.1016/j.cryobiol.2008.10.126

[32] VIEWEG J, DANNULL J Technology insight: vaccine therapy for prostate cancer. Nat Clin Pract Urol 2005; 2: 44-51. http:// dx.doi.org/10.1038/ncpuro0079

[33] FRIEDLINE RH, BROWN DS, NGUYEN H, KORNFELD $\mathrm{H}$, LEE J et al. CD4+ regulatory T cells require CTLA-4 for the maintenance of systemic tolerance. J Exp Med 2009; 206: 421-34. http://dx.doi.org/10.1084/jem.20081811 